\title{
Physiologic Characterization of Type 2 Diabetes-Related Loci
}

\author{
Niels Grarup • Thomas Sparsø • Torben Hansen
}

Published online: 1 October 2010

(C) The Author(s) 2010. This article is published with open access at Springerlink.com

\begin{abstract}
For the past two decades, genetics has been widely explored as a tool for unraveling the pathogenesis of diabetes. Many risk alleles for type 2 diabetes and hyperglycemia have been detected in recent years through massive genome-wide association studies and evidence exists that most of these variants influence pancreatic $\beta$ cell function. However, risk alleles in five loci seem to have a primary impact on insulin sensitivity. Investigations of more detailed physiologic phenotypes, such as the insulin response to intravenous glucose or the incretion hormones, are now emerging and give indications of more specific pathologic mechanisms for diabetes-related risk variants. Such studies have shed light on the function of some loci but also underlined the complex nature of disease mechanism. In the future, sequencing-based discovery of lowfrequency variants with higher impact on intermediate diabetes-related traits is a likely scenario and identification of new pathways involved in type 2 diabetes predisposition will offer opportunities for the development of novel therapeutic and preventative approaches.
\end{abstract}

Keywords Type 2 diabetes - Glycemia $\beta$-cell function . Insulin sensitivity · Genetic epidemiology Physiology

\footnotetext{
T. Hansen $(\square)$

Hagedorn Research Institute,

Niels Steensens Vej 1,

2820 Gentofte, Denmark

e-mail: toha@hagedorn.dk

N. Grarup · T. Sparsø

Diabetes Genetics, Hagedorn Research Institute,

Gentofte, Denmark
}

\section{Introduction}

Type 2 diabetes and its complications are major global health problems due to dramatically increasing prevalence in both the Western world and in the developing countries [1]. Type 2 diabetes is characterized by obesity, insulin resistance, and a relative decrease in insulin release from the $\beta$-cell. The diminished insulin response is seen as a missing first-phase insulin release after glucose stimulation and also following stimulation with nonglucose secretagogues such as the incretin hormones, glucagon-like peptide-1 (GLP-1), and gastric inhibitory polypeptide. The decreased insulin sensitivity seen in type 2 diabetes patients primarily affects the liver and peripheral tissue leading to increased hepatic glucose output and diminished glucose uptake by skeletal muscle and adipose tissue.

Despite the crucial etiologic role of lifestyle and environmental factors it has for years been recognized that genetic factors are important for the development of type 2 diabetes and related intermediary metabolic traits. The evidence of a genetic component in the pathogenesis of type 2 diabetes and related traits comes from studies of large families, twins and sibpairs, and from adoption studies. Type 2 diabetes clusters in families and offspring have a lifetime risk of developing type 2 diabetes of $35 \%$ if one parent has type 2 diabetes and $70 \%$ if both parents have type 2 diabetes compared with $10 \%$ in the general population [2], translated to a sibling relative risk of 2 to 3 [3]. In studies of monozygotic and dizygotic twins the relative importance of genetic and nongenetic factors can be estimated rather precisely under the assumption that twin pairs share the same prenatal and postnatal environment and that twins resemble singletons according to the phenotype in question [4]. Heritability estimates from twin data have shown variable concordance rates of type 2 
diabetes in monozygotic twins from nearly $100 \%$ in early studies [5] to more modest rates ranging from $35 \%$ to $70 \%$ in later reports, as opposed to $20 \%$ to $30 \%$ in dizygotic twins [6-8]. Similarly, high degrees of heritability of diabetes-related traits have been found. In studies applying intravenous glucose tolerance test (IVGTT), heritability estimates of the acute insulin response to glucose ranged from $35 \%$ to $76 \%$ [9-11]. Also, the insulin response to nonglucose stimuli is influenced by genetic factors as heritability of GLP-1- and arginine-stimulated insulin release has been estimated to $53 \%$ and $80 \%$, respectively [12]. Both basal and insulin-stimulated glucose uptake are also in part genetically determined, with heritability estimates ranging from $40 \%$ to $60 \%[10,12,13]$.

Since 1992, several genetic subtypes of monogenic diabetes have been described in which gene mutations result in diabetes primarily through $\beta$-cell dysfunction. This new knowledge means that patients who were previously categorized clinically as having maturity-onset diabetes of the young (MODY), permanent neonatal diabetes mellitus, or transient neonatal diabetes mellitus can now usually be classified by genetic subgroup. Definition of the genetic subgroup can result in appropriate treatment, genetic counseling, and prognostic information. In contrast, progress in identification of the genetic variants influencing predisposition to common forms of type 2 diabetes has, until recently, been slow. The candidate-gene approach has brought some success; however, the overall yield of confirmed diseasesusceptibility genes gathered by this approach has been limited. Technologic advances have provided tools for simultaneous genotyping of hundreds of thousands of single nucleotide polymorphisms (SNPs) in individual samples. This has allowed researchers to perform genome-wide association studies (GWAS) that do not rely on prior assumptions regarding biological candidacy, and which are capable of identifying associations within genes that had little or no previous credibility as disease candidates. Even though the unraveling of the molecular pathogenesis of type 2 diabetes is still in its infancy, the last few years have brought some very interesting progress leading to the firm establishment of many genomic loci as contributing etiologic factors in common metabolic traits as type 2 diabetes.

The objective of this review is to summarize the current human physiologic knowledge of all gene variants with a validated impact on type 2 diabetes or traits of glucose homeostasis.

\section{Physiology of Diabetes-Related Loci}

Since the discovery of risk variants in PPARG in 1998, KCNJ11 in 2003, and TCF7L2 in 2006, the emergence of GWAS in 2007 combined with access to large well- powered study populations has quickly expanded the list of validated type 2 diabetes susceptibility alleles [14]. Now 38 loci have shown association with type 2 diabetes at a genome-wide significance level $\left(P<5 \times 10^{-8}\right)$. Besides from GWAS of type 2 diabetes in case-control settings, knowledge of the genetic mechanisms in type 2 diabetes has come from GWAS of diabetes-related phenotypes such as fasting and 2-h levels of glucose and insulin during an oral glucose tolerance test (OGTT). These consortium studies have generated a list of 16 loci associated with fasting glucose and five loci associated with 2-h glucose levels $[15 \cdot 16]$, partly overlapping with each other and with the list of type 2 diabetes loci. All loci with a genome-wide significant association with type 2 diabetes or traits of glucose homeostasis are summarized in Table 1.

Given that most risk variants have been detected by the agnostic GWAS approach, the knowledge of the underlying phenotype leading to type 2 diabetes or altered glucose levels is at first very limited for most loci. Several studies have subsequently been performed with the objective to unravel intermediary phenotype of these loci to obtain a more detailed biological knowledge initially seeking to break the diabetes-related phenotype for each locus into the major components of type 2 diabetes pathogenesis being insulin release, insulin sensitivity, and obesity. These studies have taught us that a substantial part of the inherent susceptibility for type 2 diabetes relates to the extent to which pancreatic $\beta$-cell function can be maintained (Table 1). This opposes the viewpoint that the majority of type 2 diabetes genes inflict a state of insulin resistance with the $\beta$-cell simply failing to respond to the lifelong state of increased insulin demand.

\section{Loci Primarily Associated with Type 2 Diabetes}

The pancreatic $\beta$-cell has an imperative function to maintain the glucose level and malfunctions in this cell are a requisite for development of type 2 diabetes. The function of the $\beta$-cell can be evaluated in humans in different ways. Often the glucose-stimulated release of insulin or C-peptide during an OGTT has been used; however, to map $\beta$-cell defects in more detail, a range of more precise measures are warranted (eg, estimation of the acute insulin response after intravenous glucose administration, which provides an estimate of the incretinindependent $\beta$-cell function). Also, insulin release during a hyperglycemic clamp in combination with injection of incretins, sulfonylurea, glucagon, or arginine can be used to identify the more specific site of $\beta$-cell malfunction. Furthermore, a detailed understanding of genetically caused $\beta$-cell dysfunction will often be difficult to reach without also understanding the simultaneous and confounding effect of the mutation in other islet cell types and/or other tissues. 
Table 1 Overview of the physiologic impact of loci associated with a diabetes-related trait at genome-wide significance ${ }^{\mathrm{a}}$

\begin{tabular}{|c|c|c|c|c|}
\hline Nearest gene(s) & Lead SNP ${ }^{b}$ & $\begin{array}{l}\text { Genome-wide significantly } \\
\text { associated trait }\end{array}$ & $\begin{array}{l}\text { Other reported association with } \\
\text { physiologic phenotypes }\end{array}$ & Proposed mechanism \\
\hline \multicolumn{5}{|c|}{ Variants with an effect on $\beta$-cell function } \\
\hline $\begin{array}{l}\text { KCNJ11 } \\
\text { ABCC8 }\end{array}$ & $\begin{array}{l}\text { rs5219 } \\
(\mathrm{E} 23 \mathrm{~K})\end{array}$ & $\mathrm{T} 2 \mathrm{D}$ & $\begin{array}{l}\text { Reduced insulin release during } \\
\text { OGTT }[20,31,34] \\
\text { Increased glucagon levels } \\
\text { during hyperglycemic } \\
\text { clamp [79] }\end{array}$ & $\begin{array}{l}\text { Impaired } \beta \text {-cell function } \\
\text { and impaired glucagon } \\
\text { suppression }\end{array}$ \\
\hline TCF7L2 & $\begin{array}{l}\text { rs } 7901695 \\
\text { rs } 7903146\end{array}$ & T2D, FG, 2 h-G & $\begin{array}{l}\text { Impaired conversion of } \\
\text { proinsulin to insulin } \\
{[39,40 \bullet \bullet, 80]} \\
\text { Reduced insulin release during } \\
\text { OGTT }[34,40 \bullet \bullet, 80,81] \\
\text { Reduced incretin effect } \\
{[42,43 \cdot, 44,45]} \\
\text { Reduced glucagon levels }[44]\end{array}$ & $\begin{array}{l}\text { Impaired incretin-stimulated } \\
\text { insulin release } \\
\text { Impaired expression of } \\
\text { prohormone convertases }\end{array}$ \\
\hline WFS1 & rs10010131 & $\mathrm{T} 2 \mathrm{D}$ & $\begin{array}{l}\text { Reduced insulin release during } \\
\text { OGTT }[18,19,46] \\
\text { Reduced GLP-1 induced insulin } \\
\text { release during hyperglycemic } \\
\text { clamps [46] }\end{array}$ & $\begin{array}{l}\text { Impaired incretin-stimulated } \\
\text { insulin release }\end{array}$ \\
\hline $\begin{array}{l}\text { HHEX } \\
I D E\end{array}$ & $\begin{array}{l}\text { rs } 1111875 \\
\text { rs5015480 }\end{array}$ & $\mathrm{T} 2 \mathrm{D}$ & $\begin{array}{l}\text { Reduced insulin release during } \\
\text { OGTT }[22 \bullet], 23 \bullet, 24 \bullet, 34] \\
\text { Borderline significant reduced } \\
\text { insulin release during IV glucose } \\
\text { stimulation }[22 \bullet, 24 \bullet, 35-37] \\
\text { Reduced birth weight }[67,82]\end{array}$ & $\beta$-cell dysfunction \\
\hline SLC30A8 & $\begin{array}{l}\text { rs13266634 } \\
(\mathrm{R} 325 W)\end{array}$ & $\mathrm{T} 2 \mathrm{D}, \mathrm{FG}$ & $\begin{array}{l}\text { Impaired conversion of } \\
\text { proinsulin to insulin }[39,40 \bullet \bullet] \\
\text { Reduced insulin release during } \\
\text { OGTT }[24 \bullet, 30,34,40 \bullet \cdot] \\
\text { Reduced insulin release during } \\
\text { IVGTT }[24 \bullet, 25]\end{array}$ & $\begin{array}{l}\text { Impaired formation of } \\
\text { insulin granules impairing } \\
\text { insulin release }\end{array}$ \\
\hline$C D K A L 1$ & rs10946398 & $\mathrm{T} 2 \mathrm{D}$ & $\begin{array}{l}\text { Impaired conversion of } \\
\text { proinsulin to insulin [39] } \\
\text { Reduced insulin release during } \\
\text { OGTT }[21,23 \cdot, 34] \\
\text { Reduced insulin release after IV } \\
\text { glucose stimulation }[35,83] \\
\text { Reduced birth weight }[67,82,84]\end{array}$ & $\beta$-cell dysfunction \\
\hline $\begin{array}{l}C D K N 2 A \\
C D K N 2 B\end{array}$ & rs10811661 & $\mathrm{T} 2 \mathrm{D}$ & $\begin{array}{l}\text { Reduced insulin release during } \\
\text { OGTT }[22 \bullet,[30] \\
\text { Reduced insulin release during } \\
\text { IVGTT }[22 \bullet]\end{array}$ & $\beta$-cell dysfunction \\
\hline$I G F 2 B P 2$ & rs4402960 & $\mathrm{T} 2 \mathrm{D}$ & $\begin{array}{l}\text { Reduced insulin release during } \\
\text { OGTT }[22 \bullet, 30,34] \\
\text { Reduced insulin release during } \\
\text { IVGTT }[22 \cdot, 35] \\
\text { Reduced insulin release after IV } \\
\text { tolbutamide stimulation }[22 \cdot]\end{array}$ & $\beta$-cell dysfunction \\
\hline$K C N Q 1$ & rs2237895 & $\mathrm{T} 2 \mathrm{D}$ & $\begin{array}{l}\text { Reduced insulin release during } \\
\text { OGTT }[28,47] \\
\text { Reduced glucose-stimulated } \\
\text { incretin secretion [47] }\end{array}$ & $\begin{array}{l}\text { Decreased incretin } \\
\text { secretion }\end{array}$ \\
\hline$J A Z F 1$ & rs864745 & $\mathrm{T} 2 \mathrm{D}$ & $\begin{array}{l}\text { Reduced insulin release derived } \\
\text { from OGTT }[26]\end{array}$ & $\begin{array}{l}\text { Possibly } \beta \text {-cell } \\
\text { dysfunction }\end{array}$ \\
\hline
\end{tabular}


Table 1 (continued)

\begin{tabular}{|c|c|c|c|c|}
\hline Nearest gene(s) & Lead SNP ${ }^{\mathrm{b}}$ & $\begin{array}{l}\text { Genome-wide significantly } \\
\text { associated trait }\end{array}$ & $\begin{array}{l}\text { Other reported association with } \\
\text { physiologic phenotypes }\end{array}$ & Proposed mechanism \\
\hline $\begin{array}{l}\text { CDC123 } \\
\text { CAMK1D }\end{array}$ & rs12779790 & $\mathrm{T} 2 \mathrm{D}$ & $\begin{array}{l}\text { Reduced insulin release during } \\
\text { OGTT [26] } \\
\text { Reduced arginine-stimulated } \\
\text { and second-phase } \\
\text { glucose-stimulated insulin } \\
\text { release during hyperglycemic } \\
\text { clamp [48•] }\end{array}$ & Reduced $\beta$-cell mass \\
\hline THADA & $\begin{array}{l}\text { rs } 7578597 \\
(\mathrm{~T} 1187 \mathrm{~A})\end{array}$ & $\mathrm{T} 2 \mathrm{D}$ & $\begin{array}{l}\text { Reduced GLP-1—and } \\
\text { arginine-stimulated insulin } \\
\text { release during hyperglycemic } \\
\text { clamp [48•] }\end{array}$ & $\begin{array}{l}\text { Reduced } \beta \text {-cell mass } \\
\text { due to increased } \\
\text { apoptosis }\end{array}$ \\
\hline$M A D D$ & rs7944584 & FG & Higher fasting proinsulin $[40 \bullet \bullet]$ & $\begin{array}{l}\text { Insulin processing } \\
\text { defect }\end{array}$ \\
\hline$A D R A 2 A$ & rs 10885122 & FG & $\begin{array}{l}\text { Reduced insulin release during } \\
\text { OGTT [66] }\end{array}$ & $\beta$-cell dysfunction \\
\hline TSPAN8 & rs7961581 & $\mathrm{T} 2 \mathrm{D}$ & $\begin{array}{l}\text { Reduced insulin release during } \\
\text { OGTT [26] }\end{array}$ & $\begin{array}{l}\text { Possibly } \beta \text {-cell } \\
\text { dysfunction }\end{array}$ \\
\hline$M T N R 1 B$ & rs 10830963 & $\begin{array}{l}\text { FG, } \\
\text { T2D }\end{array}$ & $\begin{array}{l}\text { Reduced insulin release during } \\
\text { OGTT }[27 \bullet \bullet, 29,34,40 \bullet \bullet, 64] \\
\text { Reduced insulin released during } \\
\text { IVGTT }[29,34,48 \bullet, 64]\end{array}$ & $\begin{array}{l}\text { Impaired melatonin- } \\
\text { stimulated insulin } \\
\text { release }\end{array}$ \\
\hline FADS1 & rs 174550 & FG & $\begin{array}{l}\text { Reduced insulin release during } \\
\text { OGTT }[40 \bullet \bullet, 66]\end{array}$ & $\beta$-cell dysfunction \\
\hline GLIS3 & rs7034200 & FG & $\begin{array}{l}\text { Reduced insulin release during } \\
\text { OGTT [66] }\end{array}$ & $\begin{array}{l}\text { Possibly } \beta \text {-cell } \\
\text { dysfunction }\end{array}$ \\
\hline$C 2 C D 4 B$ & rs11071657 & FG & $\begin{array}{l}\text { Reduced insulin release during } \\
\text { OGTT }[40 \bullet \bullet, 66] \\
\text { Increased fasting proinsulin }[40 \bullet \bullet\end{array}$ & $\begin{array}{l}\text { Impaired insulin } \\
\text { processing } \\
\text { and release }\end{array}$ \\
\hline PROX1 & rs340874 & FG, T2D & $\begin{array}{l}\text { Reduced insulin release during } \\
\text { OGTT }[40 \bullet \bullet, 66]\end{array}$ & $\beta$-cell dysfunction \\
\hline$G C K$ & $\begin{array}{l}\text { rs1799884 } \\
(-30 G>A)\end{array}$ & FG, T2D & $\begin{array}{l}\text { Increased glucose levels during } \\
\text { OGTT [59] } \\
\text { Reduced insulin release derived } \\
\text { from OGTT }[40 \bullet \cdot]\end{array}$ & $\begin{array}{l}\text { Increased glucostatic set } \\
\text { point and impaired } \\
\beta \text {-cell function }\end{array}$ \\
\hline $\begin{array}{l}\text { DGKB } \\
\text { TMEM195 }\end{array}$ & rs2191349 & FG, T2D & $\begin{array}{l}\text { Reduced insulin release during } \\
\text { OGTT }[40 \bullet \bullet, 66]\end{array}$ & $\beta$-cell dysfunction \\
\hline G6PC2 & rs560887 & FG & $\begin{array}{l}\text { Increased insulin release during } \\
\text { OGTT }[40 \cdot \bullet, 65] \\
\text { Increased insulin release during } \\
\text { IVGTT [65] } \\
\text { Increased basal hepatic glucose } \\
\text { production }[65] \\
\text { Decreased risk of T2D }[16,63]\end{array}$ & Unknown \\
\hline$G I P R$ & rs10423928 & $2 \mathrm{~h}-\mathrm{G}$ & $\begin{array}{l}\text { Reduced insulin release during } \\
\text { OGTT }[15 \bullet, 40] \bullet \\
\text { Increased fasting proinsulin }[40 \bullet \bullet] \\
\text { Impaired incretin effect }[15 \bullet]\end{array}$ & $\begin{array}{l}\text { Impaired incretin-stimulated } \\
\text { insulin release } \\
\text { Impaired insulin processing }\end{array}$ \\
\hline CENTD2 & rs 1552224 & $\mathrm{~T} 2 \mathrm{D}$ & Lower HOMA-B [49] & Impaired $\beta$-cell function \\
\hline \multicolumn{5}{|c|}{ Variants with an effect on insulin sensitivity } \\
\hline PPARG & $\begin{array}{l}\text { rs1801282 } \\
(\mathrm{P} 12 \mathrm{~A})\end{array}$ & $\mathrm{T} 2 \mathrm{D}$ & $\begin{array}{l}\text { Decreased insulin sensitivity } \\
\text { derived from IVGTT and } \\
\text { hyperinsulinemic-euglycemic } \\
\text { clamp [51] }\end{array}$ & Whole-body insulin resistance \\
\hline ADAMTS9 & rs4607103 & $\mathrm{T} 2 \mathrm{D}$ & $\begin{array}{l}\text { Reduced insulin-stimulated } \\
\text { glucose uptake during } \\
\text { hyperinsulinemic-euglycemic } \\
\text { clamp [53] }\end{array}$ & Peripheral insulin resistance \\
\hline
\end{tabular}


Table 1 (continued)

\begin{tabular}{|c|c|c|c|c|}
\hline Nearest gene(s) & Lead $\mathrm{SNP}^{\mathrm{b}}$ & $\begin{array}{l}\text { Genome-wide significantly } \\
\text { associated trait }\end{array}$ & $\begin{array}{l}\text { Other reported association with } \\
\text { physiologic phenotypes }\end{array}$ & Proposed mechanism \\
\hline & & & $\begin{array}{l}\text { Increased glucose-stimulated } \\
\text { insulin release }[48 \cdot 53]\end{array}$ & \\
\hline \multirow[t]{2}{*}{$G C K R$} & rs780094 & FG, T2D, 2 h-G, triglyceride & $\begin{array}{l}\text { Increased insulin resistance } \\
\text { derived from fasting and OGTT } \\
{[16,40 \bullet \bullet, 55,57]}\end{array}$ & $\begin{array}{l}\text { Hepatic insulin } \\
\text { resistance }\end{array}$ \\
\hline & $\begin{array}{l}\text { rs1260326 } \\
(\mathrm{L} 446 \mathrm{P})\end{array}$ & & $\begin{array}{l}\text { Increased insulin-stimulated } \\
\text { hepatic glucose output [56] }\end{array}$ & \\
\hline IRS1 & rs2943641 & $\mathrm{T} 2 \mathrm{D}$ & $\begin{array}{l}\text { Increased insulin resistance } \\
\text { derived from fasting and } \\
\text { OGTT }[52 \bullet \bullet]\end{array}$ & $\begin{array}{l}\text { Whole-body insulin } \\
\text { resistance }\end{array}$ \\
\hline$I G F 1$ & rs35767 & FI & Increased HOMA-IR [16] & Whole-body insulin \\
\hline & & & $\begin{array}{l}\text { Decreased OGTT-based insulin } \\
\text { sensitivity }[40 \bullet \bullet\end{array}$ & resistance \\
\hline \multicolumn{5}{|c|}{ Variants with an effect on adiposity } \\
\hline FTO & $\begin{array}{l}\text { rs } 8050136 \\
\text { rs } 9939609\end{array}$ & BMI, $\mathrm{T}^{\mathrm{D}} \mathrm{D}^{\mathrm{c}}$ & $\begin{array}{l}\text { BMI-dependent insulin } \\
\text { resistance }[70,71]\end{array}$ & $\begin{array}{l}\text { Increased BMI-dependent } \\
\text { insulin resistance }\end{array}$ \\
\hline \multicolumn{5}{|c|}{ Variants with unknown physiology } \\
\hline$H N F 1 B$ & rs4430796 & $\mathrm{T} 2 \mathrm{D}$ & & Unknown \\
\hline$A D C Y 5$ & $\begin{array}{l}\text { rs } 11708067 \\
\text { rs2877716 }\end{array}$ & $\begin{array}{l}\text { FG, } 2 \text { h-G, T2D, } \\
\text { birth weight }\end{array}$ & Decreased birth weight $[67,68]$ & Unknown \\
\hline $\mathrm{NOTCH} 2$ & rs10923931 & $\mathrm{T} 2 \mathrm{D}$ & & Unknown \\
\hline$C R Y 2$ & rs11605924 & FG & & Unknown \\
\hline$S L C 2 A 2$ & rs11920090 & FG & & Unknown \\
\hline RBMS1 & rs 7593730 & $\mathrm{~T} 2 \mathrm{D}$ & Increased HOMA-IR [54] & Unknown \\
\hline$K L F 14$ & rs972283 & $\mathrm{T} 2 \mathrm{D}$ & $\begin{array}{l}\text { Increased fasting insulin } \\
\text { and HOMA-IR [49] }\end{array}$ & Unknown \\
\hline$B C L 11 A$ & rs243021 & $\mathrm{T} 2 \mathrm{D}$ & & Unknown \\
\hline ZBED3 & rs4457053 & $\mathrm{T} 2 \mathrm{D}$ & & Unknown \\
\hline TP53INP1 & rs896854 & $\mathrm{T} 2 \mathrm{D}$ & & Unknown \\
\hline CHCHD9 & rs13292136 & $\mathrm{T} 2 \mathrm{D}$ & & Unknown \\
\hline$K C N Q 1$ & rs231362 & $\mathrm{T} 2 \mathrm{D}$ & & Unknown \\
\hline$H M G A 2$ & rs 1531343 & $\mathrm{~T} 2 \mathrm{D}$ & & Unknown \\
\hline$H N F 1 A$ & rs7957197 & $\mathrm{T} 2 \mathrm{D}$ & & Unknown \\
\hline ZFAND6 & rs11634397 & $\mathrm{T} 2 \mathrm{D}$ & & Unknown \\
\hline PRC1 & rs 8042680 & $\mathrm{~T} 2 \mathrm{D}$ & & Unknown \\
\hline$D U S P 9$ & rs5945326 & $\mathrm{T} 2 \mathrm{D}$ & & Unknown \\
\hline VPS13C & rs17271305 & $2 \mathrm{~h}-\mathrm{G}$ & & Unknown \\
\hline
\end{tabular}

$B M I$ body mass index, $F G$ fasting glucose, $F I$ fasting insulin, $G L P$-1 glucagon-like peptide-1, HOMA-B homeostasis model assessment of $\beta$-cell function, HOMA-IR homeostasis model assessment of insulin resistance, $I V$ intravenous, IVGTT intravenous glucose tolerance test, OGTT oral glucose tolerance test, $S N P$ single nucleotide polymorphism, $T 2 D$ type 2 diabetes, $2 h-G$ 2-h glucose

${ }^{\mathrm{a}}$ All effects are stated for the allele increasing risk of T2D or increasing fasting $/ 2 \mathrm{~h}-\mathrm{G}$ or insulin

${ }^{\mathrm{b}}$ Functional SNPs in bold

${ }^{\mathrm{c}}$ FTO is only associated with T2D when not adjusting for the effect on BMI

Numerous studies have been performed investigating the glucose-stimulated insulin response in carriers and noncarriers of type 2 diabetes risk alleles and have shown that many of these variants affect this aspect of diabetes pathogenesis. This is the case for risk alleles in or near KCNJ11, TCF7L2, WFS1, CDKN2A, HHEX, IGF2BP2,
CDKAL1, SLC30A8, JAZF1, CDC123, TSPAN8, MTNR1B, and $K C N Q 1$ [17-21, 22•, 23•, 24•, 25, 26, 27••, 28-31], although results for some of the recently identified diabetes risk variants are somewhat conflicting [26, 32-34]. Growing evidence supports the notion that these risk alleles influence different aspects of $\beta$-cell function. CDKAL1, 
CDKN2A, HHEX, IGF2BP2, MTNR1B, and SLC3OA8 have been shown to inflict lower insulin response to intravenous glucose, indicating an incretin-independent pathogenesis [22•, 24•, 25, 27••, 29, 35-37]. For SLC30A8 a rather detailed knowledge of diabetogenic mechanisms has been disclosed. The SLC $30 A 8$ association signal is limited to an interval containing a single biological candidate, a zinc transporter expressed exclusively in $\beta$-cells and implicated in the maintenance of insulin granule function [38]. The strongest association is with a SNP that changes the amino acid structure of the encoded protein (R325W, which may well be the causal variant. Carriers of the R325W variant are characterized by a reduced serum insulin response following both an intravenous and an oral glucose challenge and with defective proinsulin conversion as indicated by higher fasting and orally glucose-stimulated proinsulin levels $[21,24 \bullet, 39,40 \bullet \cdot$. It is speculated whether the $\mathrm{R} 325 \mathrm{~W}$ variant also indirectly has an effect on glucagon secretion from $\alpha$ cells via an altered zinc release from the $\beta$-cells [41]. Stimulating the SLC30A8encoded zinc transporter production and/or activity may potentially be a novel approach in the treatment of type 2 diabetes patients, in who zinc depletion is likely to participate in both acute and chronic $\beta$-cell dysfunction.

Decreased incretin secretion and/or signaling could also be involved in altered $\beta$-cell function. A recent study investigated detailed phenotypes in a small number of TCF7L2 risk and non-risk allele carriers and observed a 30\% lower $\beta$-cell sensitivity to incretins in risk-allele carriers [42], which is in line with earlier observations $[43 \cdot, 44,45]$. The genotypespecific incretin-induced insulin release has also been tested for other diabetes-related risk alleles and, besides $T C F 7 L 2$, risk alleles in or near KCNJ11, KCNQ1, WFS1, and THADA influence secretion or action of the incretin hormones as evidenced by studies of hyperglycemic clamp combined with GLP-1 infusion [46, 47, 48•]. Recently, the DIAGRAM (Diabetes Genetics Replication and Meta-analysis) consortium published the results of an updated meta-analysis combining eight GWAS (8130 type 2 diabetes cases and 38,987 controls in the discovery data), additionally identifying 12 novel type 2 diabetes loci including a new independent signal in KCNQ1 [49]. No detailed physiologic studies have been published on these loci but the discovery paper investigated the basal homeostasis model assessment (HOMA) indices of $\beta$-cell function and insulin resistance in about 37,000 individuals. These data suggest that the diabetes-risk allele in CENTD2 is associated with lower basal $\beta$-cell function, whereas the KLF14 locus may inflict risk of diabetes by increasing insulin resistance [49]. If confirmed, the KLF14 locus will add to the rather short list of diabetogenic alleles with an effect on this major component of type 2 diabetes pathogenesis.
Years ago, it was recognized that the $\mathrm{P} 12 \mathrm{~A}$ variant in $P P A R G$, an important transcription factor regulating adipocyte differentiation, lipid and glucose homeostasis, and insulin sensitivity, had a type 2 diabetogenic effect caused by lower insulin sensitivity in peripheral insulin target tissues $[50,51]$. More recently, a variant located $500 \mathrm{~kb}$ upstream of IRS1 was demonstrated to increase risk of type 2 diabetes and decrease insulin sensitivity through lowering of expression of IRSI and diminishing insulin signaling [52••]. The ADAMTS9 diabetes-associated allele has also been associated with decreased insulin sensitivity, as estimated from the euglycemic-hyperinsulinemic clamp [53]; however, others investigating fasting and OGTTbased insulin sensitivity indices have not been able to detect a significant effect [26, 33]. Future larger studies estimating tissue-specific insulin sensitivity and/or metaanalysis may clarify these inconsistencies. Although it seems evident that PPARG primarily exerts its effect in adipose tissue and IRSI possibly in skeletal muscle, the putative tissue-specific site of action for ADAMTS9 has not been determined. One may argue that the lack of effect on basal HOMA of insulin resistance (HOMA-IR) in large samples reflects that a possible insulin-desensitizing effect is not acting in the liver.

In the spring of 2010 a GWAS was published demonstrating the genome-significant association of a SNP near RBMS1 [54]. Of interest, the lead SNP showed borderline significant association with increased insulin resistance as estimated from HOMA-IR in data provided by the MAGIC (Meta-Analysis of Glucose and Insulin-related Traits Consortium). Despite the huge sample size, the impact on measures of insulin resistance needs validation and refining in further studies.

Finally, variation in $G C K R$ has also been shown to influence insulin action. Initially, $G C K R$ was found to associate with increased triglyceride levels [55]. Subsequent studies identified the nonsynonymous GCKR P446L variant to be the functional variant and demonstrated that the allele reported to be associated with elevated triglyceride levels also associated with decreased plasma glucose levels and vice versa. The genome-wide significant type 2 diabetes risk allele also associated with elevated fasting glucose and elevated levels of insulin during OGTT, demonstrating an insulin resistance phenotype as the probable cause of type 2 diabetes [15•, 16, 56, 57]. The association with OGTT-based insulin sensitivity indices was replicated in 2010 in a large-scale meta-analysis including OGTT data on about 15,000 participants [40••]. GCKR associates with basal HOMA-IR, with glucosestimulated insulin sensitivity, and in a small study sample with increased hepatic glucose output during hyperinsulinemia [56]. 
Loci Primarily Associated with Quantitative Traits in Glucose Homeostasis

Also, GWAS of quantitative diabetes-related traits have contributed to the genetic understanding of type 2 diabetes and intermediate phenotypes. Mutations in $G C K$ cause a mild subtype of MODY and also the common $-30 \mathrm{G}>\mathrm{A}$ polymorphism of the $\beta$-cell specific $G C K$ promoter is an important player in regulation of fasting glycemia in the general population $[58,59]$. Interestingly, despite acting as the glucose sensor of the $\beta$-cell and despite conferring a replicated allelic approximately $0.06-\mathrm{mM}$ change in fasting plasma glucose levels, this variant has shown inconsistent association with glucose-stimulated insulin release [40••, 59] and only modest association (OR, 1.05) with type 2 diabetes [16].

By the first wave of GWAS two additional loci, G6PC2 and $M T N R 1 B$, regulating fasting glucose levels were identified [27••, 60-63]. Initial and subsequent studies have implicated variants in MTNR1B in the risk of type 2 diabetes and decreased insulin release after both oral and intravenous glucose stimulation, thereby seemingly acting independent of the incretin hormones [27••, 64]. Although variants in MTNRIB show the expected relationship between effects on fasting glucose, type 2 diabetes, and pancreatic $\beta$-cell function, a variant in the G6PC2 locus surprisingly shows association with elevated fasting glucose, decreased risk of type 2 diabetes [16, 63], increased risk of impaired fasting glycemia, [65] and increased $\beta$-cell function after both oral and intravenous glucose loads $[40 \bullet$, 65]. In addition, weak association with increased insulinstimulated hepatic glucose output has been reported [65]. These complex results leave no clear physiologic footprint because they are not concordant with merely an elevation of the glucostatic set point. However, it has been suggested that results are due to an imbalance between $G C K$ and G6PC2 leading to disturbance of the pulsatile insulin secretion, which is correlated with oscillations in glycolysis $[40 \bullet \cdot$; yet, this hypothesis remains to be tested.

Recent analyses of quantitative glucose traits in huge GWAS meta-analyses performed by MAGIC including more than 45,000 individuals in the discovery stage found a total of 16 loci associated with fasting glucose levels, two loci associated with fasting insulin and HOMA-IR, and five loci associated with 2-h glucose levels during an OGTT $[15 \cdot 16]$. As might be expected, the list of fasting and 2-h glucose-associated loci is partly overlapping with each other and with the list of type 2 diabetes loci (Table 1).

Of the five known and novel loci associated with 2h OGTT plasma glucose, the GIPR glucose-raising allele showed a strong effect on orally glucose-stimulated insulin release in about 19,500 individuals in the initial discovery paper [15•]. A lack of influence on intravenous glucosestimulated insulin in 1509 individuals and a diminished incretin effect when comparing insulin response to oral versus intravenous glucose give evidence of an incretinmediated mechanism [15•]. Paradoxically, this variant only showed nominal significant low-impact association (OR, 1.07 ) with type 2 diabetes [15 $]$. Notably, the lead SNP, rs10423928, is in strong linkage disequilibrium (LD) $\left(r^{2}=\right.$ 0.93 ) with the nonsynonymous GIPR E354Q substitution, which is likely to be the functional variant. The other novel variants associated with 2 -h plasma glucose during an OGTT in the ADCY5 and VPS13C loci show no clear diabetes-related intermediate phenotype $[16,40 \bullet \bullet, 66]$, although $A D C Y 5$ has been associated with decreased birth weight $[67,68]$. Another variant in $A D C Y 5$ in high LD was simultaneously associated with both fasting glucose and type 2 diabetes [16], yet does not associate with intermediary phenotypes of glucose metabolism $[40 \bullet \bullet, 66]$.

In contrary, of the 10 novel fasting glucose-raising alleles, many show association with decreased insulin release during OGTT indicating a general $\beta$-cell dysfunction. This seems to be the case for variants in $D G K B$, C2CD4B, GLIS3, ADRA2A, PROX1, and FADS1 [40••, 66]. Interestingly, alleles at TCF7L2, SLC30A8, GIPR, and $C 2 C D 4 B$ loci showed increased fasting proinsulin levels in a large sample size of more than 17,000 individuals in addition to decreased orally stimulated insulin release [40••], supporting earlier observations in smaller settings for TCF7L2 and SLC30A8 risk alleles [39]. This indicates a state of $\beta$-cell stress with deficient insulin processing and accumulation of insulin precursor molecules as the intermediate mechanism for $\beta$-cell dysfunction, hyperglycemia, and overt type 2 diabetes. For TCF $7 L 2$, an additional or alternative mechanism for elevated proinsulin levels might be decreased expression of both major genes involved in proinsulin processing (PCSK1 and PCSK2), which contain $T C F 7 L 2$ binding sites in their promoters.

One novel locus, $I G F 1$, was associated with fasting insulin and HOMA-IR [16] and the effect on insulin resistance has since been replicated by OGTT-based insulin sensitivity indices [40••]. However, the effect is minute (0.5-2\% change per allele) and was not statistically significant in 5722 Danish individuals [66] nor in intravenous measurements in 3195 individuals of the former study $[40 \bullet \cdot$.

Loci Primarily Associated with Adiposity

Obesity is a major characteristic of type 2 diabetes and one might expect the existence of many common susceptibility alleles for obesity and type 2 diabetes. However, GWAS of 
type 2 diabetes and obesity and subsequent association studies have showed that this is not the case. To date, only variation in FTO has been convincingly shown to impact type 2 diabetes by an intermediate effect on body mass index (BMI) and adiposity [69]. In addition, variation in FTO has revealed association with metabolic phenotypes showing the expected insulin resistance phenotype [70, 71]; however, these effects can be fully explained by the correlation between BMI and traits of insulin resistance [72]. Interestingly, a significant interaction between the FTO variant and low physical activity on body fat accumulation and insulin sensitivity has been reported [70].

\section{What Have We Learned?}

Genetic Overlap Between Type 2 Diabetes and DiabetesDefining Glucose Traits

As evidenced by the former sections and by Table 1, many loci showing genome-wide significant association with type 2 diabetes and quantitative traits of glucose homeostasis have been detected. Given the fact that diabetes is defined by glucose levels in the fasting state and at $2 \mathrm{~h}$ during an OGTT, one would intuitively expect a considerable overlap between the predisposing genetic factors for these three entities. However, recent discoveries have shown that this is not the case. Some loci (eg, TCF7L2, SLC30A8, and $G C K R$ ) show a validated association with both fasting glucose and type 2 diabetes, yet other loci associate only with fasting or 2-h glucose levels (eg, SLC2A2) or type 2 diabetes (eg, $H N F 1 B$ and $J A Z F 1$ ). At the extremity, the risk allele near $G 6 P C 2$ both increases fasting glucose $[60,61]$ and decreases risk of type 2 diabetes [16, 63].

This apparent paradox raises some interesting issues to be considered. First, quantitative GWAS of glucose traits have all been performed in nondiabetic individuals from the general population, whereas type 2 diabetes loci have been found in studies of disease cases and population controls. Therefore, it is possible that the genetic determinants of glucose levels in the general population are somewhat different from the genetic elements pushing glucose levels to diabetes-defining levels. In this sense diabetes-associated alleles without an impact on glucose levels in the general population would act above a certain glucose threshold. Second, the impact of genetic variants may be agedependent because quantitative investigations have foremost been performed in middle-aged individuals, whereas ascertained type 2 diabetes cases are generally older. Yet of importance, these coherences between glucose-raising and diabetes-associated alleles may change considerably when causal alleles of the known loci are found. Interestingly, there seems to be an equal fraction of loci with an impact on $\beta$-cell function among glucose-raising alleles and diabetes-associated alleles (Table 1).

\section{The Combined Effect of Multiple Risk Alleles}

As evidenced above and in Table 1, the majority of diabetes-related SNPs seem to inflict a change in the function of the pancreatic $\beta$-cell. Besides SNP-by-SNP studies, this phenomenon has also been investigated in studies combining suspected $\beta$-cell gene variants. In 2008, Pascoe et al. [73] found an additive effect of $\beta$-cell risk alleles in CDKAL1, HHEX, and TCF7L2, which was also demonstrated in a German study of TCF7L2, CDKAL1, HHEX, and SLC30A8 [74]. Also, a Swedish prospective study found a relative decline in $\beta$-cell function in the quintile of participants carrying the highest number of type 2 diabetes risk alleles [30].

Based on estimates from population-based Inter99 of 5722 nondiabetic individuals, it is evident that the common variants depicted in Fig. 1 and Table 1 individually only have a minor effect on the examined trait. The combined impact of multiple alleles can also be investigated in relation to the extent to which they explain variation in the trait of interest in the general population. The variants depicted in Fig. 1 explain $4 \%$ to $6 \%$ of the total interindividual variation in insulinogenic index and only $1 \%$ to $3 \%$ of variation in ISI Matsuda. These figures show that a minor part of the genetic origin of diabetes-related intermediary traits in the general population has been elucidated, telling us that future studies likely will uncover many more risk loci. Also, insights into structural variation, gene-gene and gene-environment interactions, and epigenetic modifications are likely to explain the so-called missing heritability.

\section{Estimation of the Key Diabetes-Related Components:} Insulin Release and Insulin Sensitivity

For genetic studies of complex traits such as type 2 diabetes, it has in the last decade been acknowledged that large sample sizes are necessary to estimate the low-impact association with confidence. This development is also reflected in GWAS sample sizes, which now exceeds 120,000 participants including replication sample sets [16]. Also, follow-up studies in cohorts with more detailed diabetes-related phenotypes now frequently include more than 5000 individuals and, recently, the first systematic meta-analysis was performed gathering OGTT data from more than 15,000 participants [ $40 \bullet \bullet$. Yet, the sample sizes used to investigate more detailed physiologic traits are severely impeded by low sample size. This is the case for studies applying IVGTT, hyperglycemic-hyperinsulinemic or euglycemic-hyperinsulinemic clamp techniques and 


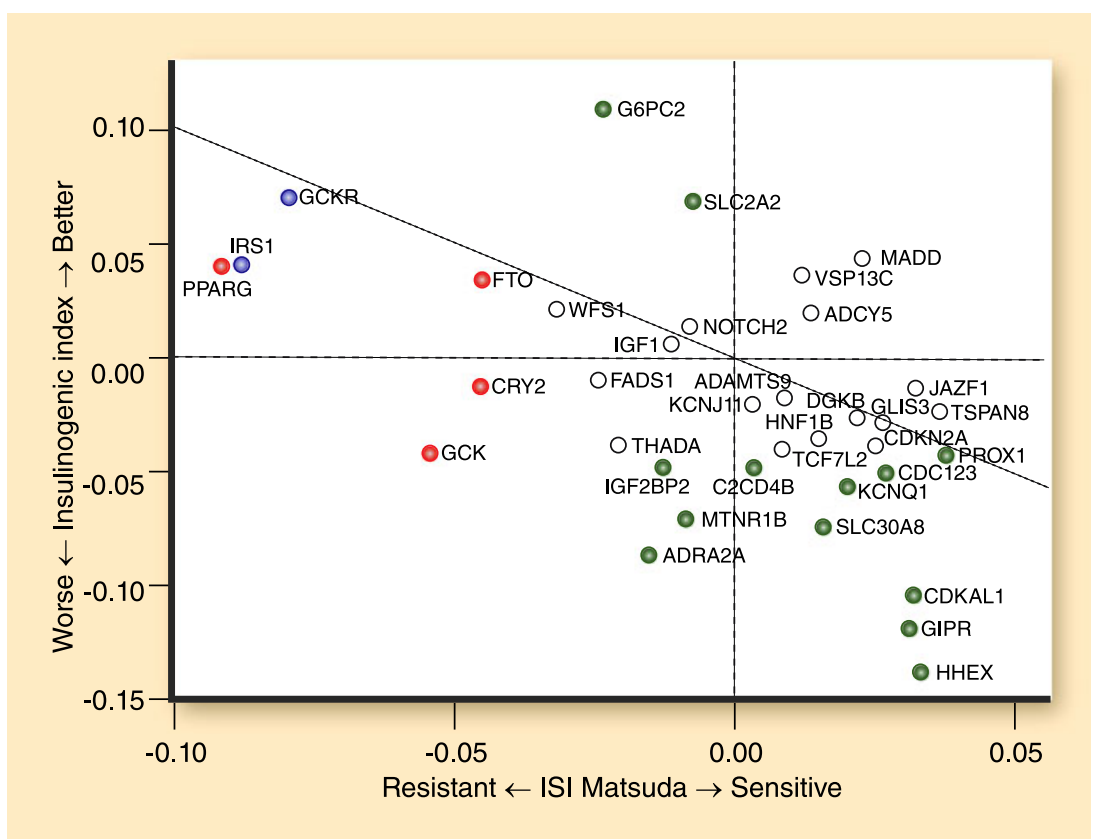

Fig. 1 Graphic representation of association with insulin sensitivity (ISI Matsuda) in relation to association with glucose-stimulated insulin release (insulinogenic index) for 36 single nucleotide polymorphisms (SNPs) with a validated impact on diabetes-related traits in 5722 nondiabetic participants of the population-based Inter99 cohort. The effect sizes are expressed as allelic change in fraction of a standard deviation and have been estimated applying a linear

entails low statistical power, risk of type 2 errors, and inability to draw robust inferences of no association. Furthermore, many associations seen in such wellcharacterized samples have only been observed in a single study calling for independent replication.

Several indices of insulin release and insulin sensitivity based on fasting and OGTT data have been validated against more precise measures, the objective being to enable large-scale, low-cost estimation of the primary intermediate components of glucose homeostasis. These estimates have in genetic studies been used to classify diabetes-related risk alleles into broad functional classes such as ones having an impact on insulin release or insulin sensitivity. Yet the question remains whether fasting and OGTT-based indices can also serve to subclassify genetic effects to designate a more precise physiologic mechanism.

\section{What's Next?}

\section{Functional Characterization of Diabetes-Related Loci}

For most loci summarized in Table 1, the causal gene and mutation leading to the described phenotype has not been determined; instead, these variants may just as well be regression model adjusted for sex and age. SNPs represented by green dots associate with altered $\beta$-cell function using the insulinogenic index $(P<0.05)$, SNPs shown in red dots associate with altered insulin sensitivity using the Matsuda insulin sensitivity index (ISI Matsuda), and SNPs shown in blue associate with altered $\beta$-cell function and altered insulin sensitivity. ISI-insulin sensitivity index

markers of indirect association. However, for a few loci the molecular effect of the actual causal variant has been discovered opening for much more detailed studies of phenotype and the underlying biology. One such example is $G C K R$ for which the initial GWAS SNP marker has been refined by fine-mapping to a nonsynonymous variant (P446L) [56], which was subsequently demonstrated to change regulation of $G C K$ in the liver and thereby influence metabolic phenotypes [75]. The functional variant (R325W) in the SLC30A8 locus has also been established and the first functional studies reported demonstrating a role in insulin granule storage [76]. However, these two examples are special cases because the initial GWAS lead SNP was a nonsynonymous variant or in high LD with a HapMapgenotyped nonsynonymous obvious candidate mutation.

Other loci in which a probable functional variant has been found includes GIPR, GCK, and PPARG. In the $K C N J 11$ locus two nonsynonymous variants in two different genes (KCNJ11 E23K and $A B C C 8 \mathrm{~S} 1369 \mathrm{~A})$ in high LD $\left(r^{2}=0.98\right.$ [31]) exist. A recent functional study provided evidence for an alteration of the function of the ATP-sensitive potassium channel in the $\beta$-cell, encoded by $K C N J 11$ and $A B C C 8$, when these two variants were coexpressed [77], possibly explaining previous inconclusive reports of investigations of a single mutation. This 
example also illustrates the extreme complexity and challenge in finding causal and functional variants in the many recently identified risk loci. For the remaining loci fine-mapping efforts and functional studies are needed to detect and characterize the mutation of interest. Identification of the functional variants will guide the design of more detailed physiologic studies, which will pave the road for a much deeper understanding of the disease mechanisms at the whole body level.

\section{Discovery of Novel Loci}

Despite the high number of validated variants with an impact on diabetes-related intermediary traits the explained proportion of variance is rather low, indicating the existence of further genetic susceptibility elements. It seems likely that future studies will discover more common risk variants by GWAS of type 2 diabetes and related traits in even larger samples. However, these variants will probably inflict very modest risk increments and physiologic characterization of such loci will be extremely challenging. Yet, also future decently powered GWAS of specific intermediate phenotypes may discover novel variants, presumably including variants with larger impact on these intermediate traits.

Another avenue in the search for gene variants that impact on the components of type 2 diabetes will probably come from the emerging sequencing studies detecting variation at low frequency in the population. It has been proposed that accumulation of multiple mildly deleterious rare, but not monogenic, gene variants in individual human genomes has a huge impact on the genetic basis for complex diseases contributing with a large relative risk at the individual level [78]. From studies of MODY we know that rare variants can cause Mendelian disease, which affects the $\beta$-cell, and it is conceivable that low-frequency variation will have a large impact in certain subsets of the population. The most efficient way to uncover such variation may be to sequence individuals at the ends of distributions of the quantitative trait of interest. The specific physiologic defects could then be investigated in detailed studies of in vivo physiology in individuals recruited by genotype in supplement to association studies at the population level.

Study Designs and Samples for the Study of Quantitative Diabetes-Related Traits

As alluded to previously, the sample size of most studies of detailed human physiology in relation to genetic variants are small, with less than 1000 participants in clamp and IVGTT studies. To close in on the more specific physiology behind crude type 2 diabetes associ- ations and thereby to learn important lessons on biology of type 2 diabetes, more individuals have to be studied with standardized detailed physiologic methods. In the near future these aspects need evaluation and the scientific community and funding agencies will need to consider spending more money on phenotypic characterization of large study samples. Of interest are also large prospective studies that will tell us about the time-dependent and lifestyle-dependent nature of risk allele penetrance.

\section{Conclusions}

Many risk alleles for type 2 diabetes and hyperglycemia have been detected in the recent years and evidence exists that most of these variants influence pancreatic $\beta$-cell function. Investigations of more detailed physiologic phenotypes, such as of the insulin response to intravenous glucose or the incretion hormones, are now emerging and give indications of more specific pathologic mechanisms for diabetes-related risk variants. Such studies have shed light on the function of some loci but also underlined the complex nature of disease mechanism. In the future the sequencing-based discovery of low-frequency variants with higher impact on intermediate diabetes-related traits is a likely scenario.

Disclosure No potential conflicts of interest relevant to this article were reported.

Open Access This article is distributed under the terms of the Creative Commons Attribution Noncommercial License which permits any noncommercial use, distribution, and reproduction in any medium, provided the original author(s) and source are credited.

\section{References}

Papers of particular interest, published recently, have been highlighted as:

- Of importance

•- Of major importance

1. Zimmet P, Alberti KG, Shaw J: Global and societal implications of the diabetes epidemic. Nature 2001, 414:782-787.

2. Köbberling J, Tillil H (1982) Empirical risk figures for first degree relatives of non-insulin dependent diabetics. In The Genetics of Diabetes Mellitus. Edited by Köbberling J, Tattersall R. London: Academic Press, pp 201-209.

3. Lyssenko V, Almgren P, Anevski D, et al.: Predictors of and longitudinal changes in insulin sensitivity and secretion preceding onset of type 2 diabetes. Diabetes 2005, 54:166-174. 
4. Vaag A, Poulsen P: Twins in metabolic and diabetes research: what do they tell us? Curr Opin Clin Nutr Metab Care 2007, 10:591-596.

5. Barnett AH, Eff C, Leslie RD, Pyke DA: Diabetes in identical twins. A study of 200 pairs. Diabetologia 1981, 20:87-93.

6. Newman B, Selby JV, King MC, et al.: Concordance for type 2 (non-insulin-dependent) diabetes mellitus in male twins. Diabetologia 1987, 30:763-768.

7. Kaprio J, Tuomilehto J, Koskenvuo M, et al.: Concordance for type 1 (insulin-dependent) and type 2 (non-insulin-dependent) diabetes mellitus in a population-based cohort of twins in Finland. Diabetologia 1992, 35:1060-1067.

8. Poulsen P, Kyvik KO, Vaag A, Beck-Nielsen H: Heritability of type II (non-insulin-dependent) diabetes mellitus and abnormal glucose tolerance - a population-based twin study. Diabetologia 1999, 42:139-145.

9. Watanabe RM, Valle T, Hauser ER, et al.: Familiality of quantitative metabolic traits in Finnish families with non-insulindependent diabetes mellitus. Finland-United States Investigation of NIDDM Genetics (FUSION) Study investigators. Hum Hered 1999, 49:159-168.

10. Lehtovirta M, Kaprio J, Forsblom C, et al.: Insulin sensitivity and insulin secretion in monozygotic and dizygotic twins. Diabetologia 2000, 43:285-293.

11. Lehtovirta M, Kaprio J, Groop L, et al.: Heritability of modelderived parameters of beta cell secretion during intravenous and oral glucose tolerance tests: a study of twins. Diabetologia 2005, 48:1604-1613.

12. Simonis-Bik AM, Eekhoff EM, de Moor MH, et al.: Genetic influences on the insulin response of the beta cell to different secretagogues. Diabetologia 2009, 52:2570-2577.

13. Poulsen P, Levin K, Petersen I, et al.: Heritability of insulin secretion, peripheral and hepatic insulin action, and intracellular glucose partitioning in young and old Danish twins. Diabetes 2005, 54:275-283.

14. McCarthy MI, Zeggini E: Genome-wide association studies in type 2 diabetes. Curr Diab Rep 2009, 9:164-171.

15. - Saxena R, Hivert MF, Langenberg $C$, et al.: Genetic variation in GIPR influences the glucose and insulin responses to an oral glucose challenge. Nat Genet 2010, 42:142-148. Discovery of variation in GIPR associated with glucose traits and impaired incretin effect and $\beta$-cell function. The paper combines novel discovery with human physiology data and simple functional studies.

16. Dupuis J, Langenberg C, Prokopenko I, et al.: New genetic loci implicated in fasting glucose homeostasis and their impact on type 2 diabetes risk. Nat Genet 2010, 42:105-116.

17. Florez JC, Jablonski KA, Bayley N, et al.: TCF7L2 polymorphisms and progression to diabetes in the Diabetes Prevention Program. N Engl J Med 2006, 355:241-250.

18. Florez JC, Jablonski KA, McAteer J, et al.: Testing of diabetesassociated WFS1 polymorphisms in the Diabetes Prevention Program. Diabetologia 2008, 51:451-457.

19. Sparsø T, Andersen G, Albrechtsen A, et al.: Impact of polymorphisms in WFS1 on prediabetic phenotypes in a populationbased sample of middle-aged people with normal and abnormal glucose regulation. Diabetologia 2008, 51:1646-1652.

20. Nielsen EM, Hansen L, Carstensen B, et al.: The E23K variant of Kir6.2 associates with impaired post-OGTT serum insulin response and increased risk of type 2 diabetes. Diabetes 2003, 52:573-577.

21. Steinthorsdottir V, Thorleifsson G, Reynisdottir I, et al.: A variant in CDKAL1 influences insulin response and risk of type 2 diabetes. Nat Genet 2007, 39:770-775.

22. - Grarup N, Rose CS, Andersson EA, et al.: Studies of association of variants near the HHEX, CDKN2A/B, and IGF2BP2 genes with type 2 diabetes and impaired insulin release in 10,705 Danish subjects: validation and extension of genome-wide association studies. Diabetes 2007, 56:3105-3111. One of the first studies to show that novel type 2 diabetes risk genes inflict a decreased $\beta$ cell function.

23. - Pascoe L, Tura A, Patel SK, et al.: Common variants of the novel type 2 diabetes genes CDKAL1 and HHEX/IDE are associated with decreased pancreatic beta-cell function. Diabetes 2007, 56:3101-3104. One of the first studies to show that novel type 2 diabetes risk genes inflict a decreased $\beta$-cell function.

24. - Staiger H, Machicao F, Stefan N, et al.: Polymorphisms within novel risk loci for type 2 diabetes determine beta-cell function. PLoS One 2007, 2:e832. One of the first studies to show that novel type 2 diabetes risk genes inflict a decreased $\beta$-cell function.

25. Boesgaard TW, Zilinskaite J, Vänttinen M, et al.: The common SLC30A8 Arg325Trp variant is associated with reduced firstphase insulin release in 846 non-diabetic offspring of type 2 diabetes patients - the EUGENE2 study. Diabetologia 2008, 51:816-820.

26. Grarup N, Andersen G, Krarup NT, et al.: Association testing of novel type 2 diabetes risk alleles in the JAZF1, CDC123/ CAMK1D, TSPAN8, THADA, ADAMTS9, and NOTCH2 loci with insulin release, insulin sensitivity, and obesity in a population-based sample of 4,516 glucose-tolerant middle-aged Danes. Diabetes 2008, 57:2534-2540.

27. •• Lyssenko V, Nagorny CL, Erdos MR, et al.: Common variant in MTNR1B associated with increased risk of type 2 diabetes and impaired early insulin secretion. Nat Genet 2009, 41:82-88. Discovery of variation in MTNR1B associated with fasting glucose and impaired $\beta$-cell function. The paper combines novel discovery with human physiology data and expression studies.

28. Yasuda K, Miyake K, Horikawa Y, et al.: Variants in KCNQ1 are associated with susceptibility to type 2 diabetes mellitus. Nat Genet 2008, 40:1092-1097.

29. Staiger H, Machicao F, Schafer SA, et al.: Polymorphisms within the novel type 2 diabetes risk locus MTNR1B determine beta-cell function. PLoS One 2008, 3:e3962.

30. Lyssenko V, Jonsson A, Almgren P, et al.: Clinical risk factors, DNA variants, and the development of type 2 diabetes. $\mathrm{N}$ Engl $\mathrm{J}$ Med 2008, 359:2220-2232.

31. Florez JC, Burtt N, de Bakker PI, et al.: Haplotype structure and genotype-phenotype correlations of the sulfonylurea receptor and the islet ATP-sensitive potassium channel gene region. Diabetes 2004, 53:1360-1368.

32. Staiger H, Machicao F, Kantartzis K, et al.: Novel meta-analysisderived type 2 diabetes risk loci do not determine prediabetic phenotypes. PLoS One 2008, 3:e3019.

33. Schleinitz D, Tonjes A, Bottcher Y, et al.: Lack of significant effects of the type 2 diabetes susceptibility loci JAZF1, CDC123/ CAMK1D, NOTCH2, ADAMTS9, THADA, and TSPAN8/LGR5 on diabetes and quantitative metabolic traits. Horm Metab Res 2010, 42:14-22.

34. Stancáková A, Kuulasmaa T, Paananen J, et al.: Association of 18 confirmed susceptibility loci for type 2 diabetes with indices of insulin release, proinsulin conversion, and insulin sensitivity in 5,327 nondiabetic Finnish men. Diabetes 2009, 58:2129-2136

35. Groenewoud MJ, Dekker JM, Fritsche A, et al.: Variants of CDKAL1 and IGF2BP2 affect first-phase insulin secretion during hyperglycaemic clamps. Diabetologia 2008, 51:1659-1663.

36. Staiger H, Stancakova A, Zilinskaite J, et al.: A candidate type 2 diabetes polymorphism near the HHEX locus affects acute glucose-stimulated insulin release in European populations: results from the EUGENE2 study. Diabetes 2008, 57:514-517.

37. Palmer ND, Goodarzi MO, Langefeld CD, et al.: Quantitative trait analysis of type 2 diabetes susceptibility loci identified from 
whole genome association studies in the Insulin Resistance Atherosclerosis Family Study. Diabetes 2008, 57:1093-1100.

38. Chimienti F, Devergnas S, Pattou F, et al.: In vivo expression and functional characterization of the zinc transporter $\mathrm{ZnT} 8$ in glucose-induced insulin secretion. J Cell Sci 2006, 119:41994206.

39. Kirchhoff K, Machicao F, Haupt A, et al.: Polymorphisms in the TCF7L2, CDKAL1 and SLC30A8 genes are associated with impaired proinsulin conversion. Diabetologia 2008, 51:597-601.

40. •- Ingelsson E, Langenberg C, Hivert MF, et al.: Detailed physiologic characterization reveals diverse mechanisms for novel genetic loci regulating glucose and insulin metabolism in humans. Diabetes 2010, 59:1266-1275. The first study to perform a largescale meta-analysis of OGTT data for known diabetes-associated loci to obtain statistical power to detect small effects on intermediary quantitative trait.

41. Slucca M, Harmon JS, Oseid EA, et al.: ATP-sensitive K+ channel mediates the zinc switch-off signal for glucagon response during glucose deprivation. Diabetes 2010, 59:128-134.

42. Villareal DT, Robertson H, Bell GI, et al.: TCF7L2 variant rs7903146 affects the risk of type 2 diabetes by modulating incretin action. Diabetes 2010, 59:479-485.

43. - Lyssenko V, Lupi R, Marchetti P, et al.: Mechanisms by which common variants in the TCF7L2 gene increase risk of type 2 diabetes. J Clin Invest 2007, 117:2155-2163. A detailed and large study showing that a risk variant in TCF7L2 has an impact on the incretion effect and TCF7L2 expression in human pancreatic islets.

44. Pilgaard K, Jensen $\mathrm{CB}$, Schou $\mathrm{JH}$, et al.: The $\mathrm{T}$ allele of rs7903146 TCF7L2 is associated with impaired insulinotropic action of incretin hormones, reduced $24 \mathrm{~h}$ profiles of plasma insulin and glucagon, and increased hepatic glucose production in young healthy men. Diabetologia 2009, 52:1298-1307.

45. Schafer SA, Tschritter O, Machicao F, et al.: Impaired glucagonlike peptide-1-induced insulin secretion in carriers of transcription factor 7-like 2 (TCF7L2) gene polymorphisms. Diabetologia 2007, 50:2443-2450.

46. Schafer SA, Mussig K, Staiger H, et al.: A common genetic variant in WFS1 determines impaired glucagon-like peptide1-induced insulin secretion. Diabetologia 2009, 52:10751082.

47. Mussig K, Staiger H, Machicao F, et al.: Association of type 2 diabetes candidate polymorphisms in KCNQ1 with incretin and insulin secretion. Diabetes 2009, 58:1715-1720.

48. - Simonis-Bik AM, Nijpels G, van Haeften TW, et al.: Gene variants in the novel type 2 diabetes loci CDC123/CAMK1D, THADA, ADAMTS9, BCL11A, and MTNR1B affect different aspects of pancreatic beta-cell function. Diabetes 2010, 59:293301. A detailed study of many type 2 diabetes risk variants by a hyperglycemic clamp combined with GLP-1 and arginine stimulation.

49. Voight BF, Scott LJ, Steinthorsdottir V, et al.: Twelve type 2 diabetes susceptibility loci identified through large-scale association analysis. Nat Genet 2010, 42:579-589.

50. Deeb SS, Fajas L, Nemoto M, et al.: A Pro12Ala substitution in PPARgamma2 associated with decreased receptor activity, lower body mass index and improved insulin sensitivity. Nat Genet 1998, 20:284-287.

51. Ek J, Andersen G, Urhammer SA, et al.: Studies of the Pro12Ala polymorphism of the peroxisome proliferator-activated receptor g2 (PPARg2) gene in relation to insulin sensitivity among glucose tolerant Caucasians. Diabetologia 2001, 44:1170-1176.

52. • Rung J, Cauchi S, Albrechtsen A, et al.: Genetic variant near IRS1 is associated with type 2 diabetes, insulin resistance and hyperinsulinemia. Nat Genet 2009, 41:1110-1115. The first finding of a variant near IRS1 associated with type 2 diabetes, insulin resistance, IRS1 expression, and insulin signaling. Combined association analysis and functional studies.

53. Boesgaard TW, Gjesing AP, Grarup N, et al.: Variant near ADAMTS9 known to associate with type 2 diabetes is related to insulin resistance in offspring of type 2 diabetes patientsEUGENE2 study. PLoS One 2009, 4:e7236.

54. Qi L, Cornelis MC, Kraft P, et al.: Genetic variants at $2 \mathrm{q} 24$ are associated with susceptibility to type 2 diabetes. Hum Mol Genet 2010, 19:2706-2715.

55. Diabetes Genetics Initiative of Broad Institute of Harvard and MIT, Lund University, and Novartis Institutes of BioMedical Research, Saxena R, Voight BF, et al.: Genome-wide association analysis identifies loci for type 2 diabetes and triglyceride levels. Science 2007, 316:1331-1336.

56. Orho-Melander $\mathrm{M}$, Melander $\mathrm{O}$, Guiducci $\mathrm{C}$, et al.: Common missense variant in the glucokinase regulatory protein gene is associated with increased plasma triglyceride and C-reactive protein but lower fasting glucose concentrations. Diabetes 2008, 57:3112-3121.

57. Sparsø T, Andersen G, Nielsen T, et al.: The GCKR rs780094 polymorphism is associated with elevated fasting serum triacylglycerol, reduced fasting and OGTT-related insulinaemia, and reduced risk of type 2 diabetes. Diabetologia 2008, 51:70-75.

58. Weedon MN, Frayling TM, Shields B, et al.: Genetic regulation of birth weight and fasting glucose by a common polymorphism in the islet cell promoter of the glucokinase gene. Diabetes 2005, 54:576-581.

59. Rose CS, Ek J, Urhammer SA, et al.: A $-30 \mathrm{G}>\mathrm{A}$ polymorphism of the beta-cell-specific glucokinase promoter associates with hyperglycemia in the general population of whites. Diabetes 2005, 54:3026-3031.

60. Chen WM, Erdos MR, Jackson AU, et al.: Variations in the G6PC2/ABCB11 genomic region are associated with fasting glucose levels. J Clin Invest 2008, 118:2620-2628.

61. Bouatia-Naji N, Rocheleau G, Van-Lommel L, et al.: A polymorphism within the G6PC2 gene is associated with fasting plasma glucose levels. Science 2008, 320:1085-1088.

62. Bouatia-Naji N, Bonnefond A, Cavalcanti-Proença C, et al.: A variant near MTNR1B is associated with increased fasting plasma glucose levels and type 2 diabetes risk. Nat Genet 2009, 41:8994.

63. Prokopenko I, Langenberg C, Florez JC, et al.: Variants in MTNR1B influence fasting glucose levels. Nat Genet 2009, 41:77-81.

64. Sparsø T, Bonnefond A, Andersson E, et al.: G-allele of intronic rs10830963 in MTNR1B confers increased risk of impaired fasting glycemia and type 2 diabetes through an impaired glucose-stimulated insulin release: studies involving 19,605 Europeans. Diabetes 2009, 58:1450-1456.

65. Rose CS, Grarup N, Krarup NT, et al.: A variant in the G6PC2/ ABCB11 locus is associated with increased fasting plasma glucose, increased basal hepatic glucose production and increased insulin release after oral and intravenous glucose loads. Diabetologia 2009, 52:2122-2129.

66. Boesgaard TW, Grarup N, Jørgensen T, et al.: Variants at DGKB/ TMEM195, ADRA2A, GLIS3 and C2CD4B loci are associated with reduced glucose-stimulated beta cell function in middle-aged Danish people. Diabetologia 2010,53:1647-1655.

67. Andersson EA, Pilgaard K, Pisinger C, et al.: Type 2 diabetes risk alleles near ADCY5, CDKAL1 and HHEX-IDE are associated with reduced birthweight. Diabetologia 2010, 53:1908-1916.

68. Freathy RM, Mook-Kanamori DO, Sovio U, et al.: Variants in ADCY5 and near CCNL1 are associated with fetal growth and birth weight. Nat Genet 2010, 42:430-435.

69. Frayling TM, Timpson NJ, Weedon MN, et al.: A common variant in the FTO gene is associated with body mass index and 
predisposes to childhood and adult obesity. Science 2007, 316:889-894.

70. Andreasen $\mathrm{CH}$, Stender-Petersen KL, Mogensen MS, et al.: Low physical activity accentuates the effect of the FTO rs9939609 polymorphism on body fat accumulation. Diabetes 2008, 57:95101.

71. Do R, Bailey SD, Desbiens K, et al.: Genetic variants of FTO influence adiposity, insulin sensitivity, leptin levels, and resting metabolic rate in the Quebec Family Study. Diabetes 2008, 57:1147-1150.

72. Freathy RM, Timpson NJ, Lawlor DA, et al.: Common variation in the FTO gene alters diabetes-related metabolic traits to the extent expected given its effect on BMI. Diabetes 2008, 57:14191426.

73. Pascoe L, Frayling TM, Weedon MN, et al.: Beta cell glucose sensitivity is decreased by $39 \%$ in non-diabetic individuals carrying multiple diabetes-risk alleles compared with those with no risk alleles. Diabetologia 2008, 51:1989-1992.

74. Haupt A, Staiger H, Schafer SA, et al.: The risk allele load accelerates the age-dependent decline in beta cell function. Diabetologia 2009, 52:457-462.

75. Beer NL, Tribble ND, McCulloch LJ, et al.: The P446L variant in GCKR associated with fasting plasma glucose and triglyceride levels exerts its effect through increased glucokinase activity in liver. Hum Mol Genet 2009, 18:4081-4088.

76. Nicolson TJ, Bellomo EA, Wijesekara $\mathrm{N}$, et al.: Insulin storage and glucose homeostasis in mice null for the granule zinc transporter ZnT8 and studies of the type 2 diabetes-associated variants. Diabetes 2009, 58:2070-2083.
77. Hamming KS, Soliman D, Matemisz LC, et al.: Coexpression of the type 2 diabetes susceptibility gene variants KCNJ11 E23K and ABCC8 S1369A alter the ATP and sulfonylurea sensitivities of the ATP-sensitive $\mathrm{K}(+)$ channel. Diabetes 2009, 58:2419-2424.

78. Kryukov GV, Pennacchio LA, Sunyaev SR: Most rare missense alleles are deleterious in humans: implications for complex disease and association studies. Am J Hum Genet 2007, 80:727-739.

79. Tschritter O, Stumvoll M, Machicao F, et al.: The prevalent Glu23Lys polymorphism in the potassium inward rectifier 6.2 (KIR6.2) gene is associated with impaired glucagon suppression in response to hyperglycemia. Diabetes 2002, 51:2854-2860.

80. Loos RJ, Franks PW, Francis RW, et al.: TCF7L2 polymorphisms modulate proinsulin levels and beta-cell function in a British Europid population. Diabetes 2007, 56:1943-1947.

81. Saxena R, Gianniny L, Burtt NP, et al.: Common single nucleotide polymorphisms in TCF7L2 are reproducibly associated with type 2 diabetes and reduce the insulin response to glucose in nondiabetic individuals. Diabetes 2006, 55:2890-2895.

82. Freathy RM, Bennett AJ, Ring SM, et al.: Type 2 diabetes risk alleles are associated with reduced size at birth. Diabetes 2009 , 58:1428-1433.

83. Stancakova A, Pihlajamaki J, Kuusisto J, et al.: Single-nucleotide polymorphism rs7754840 of CDKAL1 is associated with impaired insulin secretion in nondiabetic offspring of type 2 diabetic subjects and in a large sample of men with normal glucose tolerance. J Clin Endocrinol Metab 2008, 93:1924-1930.

84. Zhao J, Li M, Bradfield JP, et al.: Examination of type 2 diabetes loci implicates CDKAL1 as a birth weight gene. Diabetes 2009, 58:2414-2418. 